\title{
Infection related to Klebsiella pneumoniae producing carbapenemase in renal transplant patients
}

\author{
Infecção relacionada a Klebsiella pneumoniae produtora de carbapenemase em pacientes transplantados renais
}

Infección relacionada con Klebsiella pneumoniae productora de carbapenemasa en pacientes trasplantados renales

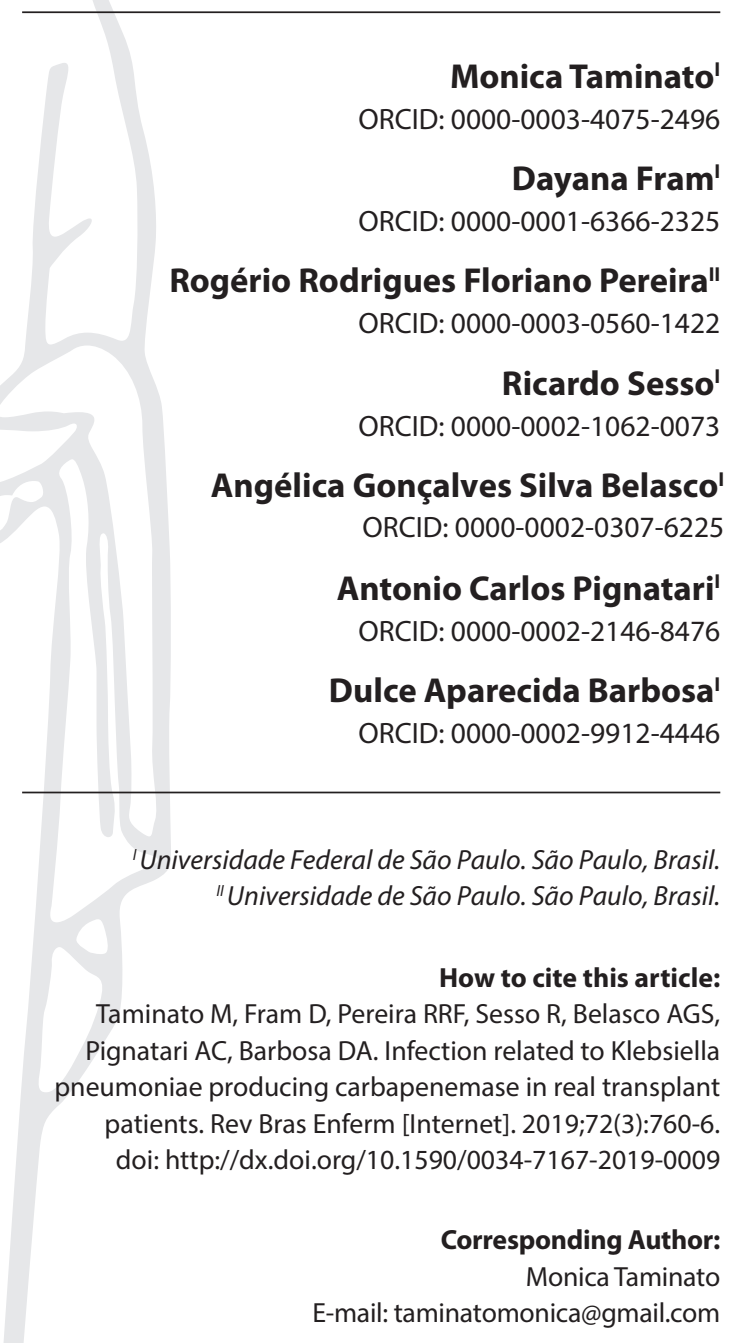

Submission: 01-11-2019 Approval: 03-23-2019

\begin{abstract}
Objective: To evaluate the risk factors related to Klebsiella pneumoniae carbapenemase infection after renal transplantation. Methods: This was a retrospective epidemiological (case-control) study, conducted from October 2011 to march 2016. Transplanted patients with infection by this bacteria during hospitalization were selected as cases. The controls were paired by age, sex, type of donor and transplant time. The proportion of cases and controls was 1:2. Results: Thirty hundred and five patients were included in the study ( 45 cases and 90 controls). The risk factors found for infection by KPC were: time of hospitalization after the transplant (OR: 4.82; Cl95\% 2.46-9.44), delayed kidney function (OR: $5.60 ; \mathrm{Cl} 95 \%$ 1.91-11.01) and previous infectious for another microorganism ( OR: 34.13 Cl95\% 3.52-132.00). Conclusion: The risk of acquisition of this bacterium was directly related to invasive procedures and exposure to the hospital environment. The findings reinforce the importance of prevention measures and control of infection by this microorganism.
\end{abstract}

Descriptors: Infection; Infection Control; Kidney Transplantation; Bacteria; Nursing Care.

\section{RESUMO}

Objetivo: Avaliar os fatores de risco relacionados à infecção por Klebsiella pneumoniae carbapenemase após o transplante renal. Método: Estudo retrospectivo epidemiológico (caso-controle), realizado de outubro de 2011 a março de 2016. Pacientes transplantados com infecção por essa bactéria durante a internação foram selecionados como casos. Os controles foram pareados por idade, sexo, tipo de doador e tempo de transplante. A proporção de casos e controles foi de 1: 2. Resultados: Trinta e cinco pacientes foram incluídos no estudo (45 casos e 90 controles). Os fatores de risco para a infecção por KPC identificados foram: tempo de hospitalização após o transplante (OR: 4,82; IC95\% 2,46-9,44), função renal retardada (OR: 5,60; IC95\% 1,91-11,01) e anterior infecciosa para outro microorganismo (OR: 34,13 IC95\% 3,52-132,00). Conclusão: O risco de aquisição dessa bactéria esteve diretamente relacionado a procedimentos invasivos e exposição ao ambiente hospitalar. Os achados reforçam a importância de medidas de prevenção e controle da infecção por esse microrganismo.

Descritores: Infecção; Controle de Infecções; Transplante Renal; Bactérias; Cuidados de Enfermagem

\section{RESUMEN}

Objetivo: Evaluar los factores de riesgo relacionados con la infección por Klebsiella pneumoniae carbapenemasa después del trasplante renal. Método: Estudio retrospectivo epidemiológico (caso-control), realizado de octubre de 2011 a marzo de 2016. Pacientes transplantados con infección por esa bacteria durante la internación fueron seleccionados como casos. Los controles se parearon por edad, sexo, tipo de donante y tiempo de trasplante. La proporción de casos y controles fue de 1: 2. Resultados: Treinta y cinco pacientes fueron incluidos en el estudio (45 casos y 90 controles). Los factores de riesgo para la infección encontrados por KPC fueron: tiempo de hospitalización después del trasplante (OR: 4,82, IC95\% 2,46-9,44), función renal retardada (OR: 5,60, IC95\% 1, 91-11,01) y anterior infecciosa para otro microorganismo (OR: 34,13 IC95\% 3,52-132,00). Conclusión: El riesgo de adquisición de esta bacteria estuvo directamente relacionado a procedimientos invasivos y exposición al ambiente hospitalario. Los hallazgos refuerzan la importancia de medidas de prevención y control de la infección por ese microorganismo.

Descriptores: Infecciones; Control de Infecciones; Transplante de Riñón; Bacteria; Atención de Enfermería. 


\section{BACKGROUND}

Management of infections caused by multidrug-resistant bacteria impacts considerably on health costs and becomes major modifier of health expenses in the ongoing antibiotic resistance crisis $^{(1)}$.

Klebsiella pneumoniae carbapenemase (KPC), has become one of the most important contemporary pathogens, among specific populations include solid organ transplantation (SOT), immunosuppressant therapy, mechanical ventilation, prolonged use of invasive devices, use of antimicrobial agents, and a high Acute Physiology and Chronic Health Evaluation score ${ }^{(2-7)}$.

Gram negative bacteria are important pathogens related to healthcare associated infections (HAls) represents a challenge for the control and treatment of infections related to this microorganism, as well as for the global dispersion of this agent ${ }^{(5-8)}$. Patients undergoing renal transplant are at risk for infection with multidrug-resistant organisms related to the surgical procedure, necessity for invasive devices, clinical complications and immunosuppression, specially in renal transplant was identified as a risk factor for the acquisition of $\mathrm{KPC}{ }^{(2,7-8)}$.

SOT recipients infected with KPC-producing Enterobacteriaceae, mortality can be as high as $71 \%{ }^{(7,9-11)}$. Among reporting that such infection occurred more frequently in the first 2 months after Kidney Transplantation, with a combined incidence of $13 \%$ in that period, and that the urinary tract was the most common site of infection. In those studies, mortality associated with KPC-HAl ranged from 33 to $50 \%{ }^{(9-11)}$.

The CDC has offered recommendations since 2009 that indicate efforts to contain dissemination, exchange information among the services, and include experiences to improve the approach to the bacteria ${ }^{(12-13)}$.

The first report of KPC in Brazil occurred in 2006, with the identification of K. pneumoniae KPC-2 in an intensive care unit (ICU) ${ }^{(14)}$.

Brazil is part of the SENTRY study, a program of antimicrobial surveillance that showed a significant increase in $\mathrm{K}$. pneumoniae KPC-2 identification between 2008-10. In 2008, isolates of KPC were not found, 10 samples were isolated in 2009, and 44 samples were positive for KPC in 2010 in the three participating Brazilian centers $^{(15)}$. This study, together with other findings, showed that $\mathrm{KPC}$ is endemic in Brazil and that this bacteria was encountered in the waste water of hospitals in the country ${ }^{(16)}$.

Facing this epidemiological panoramic of KPC, the gravity of the situation, and the fact that transplant patients are considered to be at risk for acquisition of multidrug-resistant bacteria.

\section{OBJECTIVE}

To evaluate the risk factors, investigated the epidemiology, clinical outcomes and mortality associated to KPC infection in patients undergoing renal transplant.

\section{METHODS}

\section{Ethical aspects}

The study was preceded by approval of the Ethics Committee of the Universidade Federal de São Paulo (Federal University of São Paulo, UNIFESP).

\section{Design, period and location of study}

This was a retrospective study (case-control), conducted from October 2011 to march 2016, in the Hospital do Rim e Hipertensão da Fundação Oswaldo Ramos (HRim/FOR), a university hospital and a worldwide reference in renal transplant which performs approximately 900-1000 renal transplants/year. This institution follows rigorous standards for medical record keeping.

\section{Patients}

Transplant recipients, regardless of the time of renal transplantation, who in the occasion of hospitalization developed infection with positive culture for Klebsiella pneumoniae carbapenemase (KPC), identified by active surveillance. Active surveillance of multidrug-resistant organisms is routinely performed by the Commission for the Prevention and Control of Infection of the HRim/FOR with patients hospitalized in this service ${ }^{(17)}$. Throughout the study period, surveillance cultures (perineal- rectal swab samples in Stuart's transport medium) were collected from all patients admitted from other hospitals, as well as on a weekly basis from patients in intensive care units (ICUs).

Were considered cases: renal transplant recipients (TX), aged $>18$ years; those who presented with infection at the initiation of the study with positive culture for KPC in one or more of the following samples: blood culture, urine culture; broncho-alveolar lavage; wound secretion with positive which KPC. Only the first infection was included for risk factors analysis, occurrence of death and clinical variables of interest of the case group and control were recorded for a period of one year prior to the infection by KPC.

Were considered controls: kidney transplant patients at the same institution and period of transplant, with age, sex, time of transplant (in days, the closest to the respective case), and donor type (live or deseased) similar to the cases, without positive culture for KPC or other type of infection at the initiation of the study. The ratio between the cases and controls was 1:2.

\section{Protocol and data collection}

Data collected from patient files considered cases and controls were: sociodemographic characteristics, etiology of end stage renal disease (ESRD), laboratory tests at entry into the study, results of cultures for microorganisms according to the location of standardized collection, type and duration of dialysis treatment prior to transplant, clinical complications and death, if that occurred. For identification of the risk factors, the parameters were monitored for a period of six months preceding the date of infection or colonization by KPC, and for the controls, the six months prior to the index date of enrollment was considered as the date of the pairing with the data of the TX with the respective case.The occurrence of death in both groups was verified until one week after infection by KPC.

Laboratory Methodology: For the detection of carriers of KPC, samples of blood, urine, bronchoalveolar lavage and surgical wound secretions (surgical site infection) were collected. Biological materials were sent to the Clinical Microbiology Special Laboratory (LEMC) of the Discipline of Infectious Diseases of UNIFESP, where microbiological testing was performed in accordance with the recommendations of the Clinical and Laboratory Standards Institute $(\mathrm{CLSI})^{(20)}$, which include 
isolation, identification, culture and antimicrobial sensitivity testing. Carbapenem-resistant strains of K. pneumoniae were identified with an automated susceptibility testing system (VITEK; bioMérieux, Marcy l'Étoile, France). Minimum inhibitory concentrations (MICs) were interpreted according to the Clinical and Laboratory Standards Institute breakpoints ${ }^{(18) .}$

\section{Statistical analysis}

A descriptive analysis of the cases and controls was conducted which examined the variables of interest. Data are presented using absolute frequencies and percentages for categorical variables, and mean \pm standard deviation for continuous variables. A descriptive analysis of groups of case versus control patients was conducted, considering the demographic, clinical, and laboratory parameters related to treatment. The primary results were the presence of infection by KPC at some isolated sites. The univariate analyses were performed, comparing the variables between the groups (case and control). The association between infection and categorical variables were tested with the chi-square or Fisher's exact test, and the association between continuous variables and the presence of infection was done using the Student or Mann-Whitney " $\mathrm{t}$ "-test, as appropriate. In the analysis of the associations, the odds ratios with confidence intervals at the $95 \%$ level were calculated. A multivariate analysis using logistic regression to investigate factors associated with infection/colonization was also performed. In this final analysis, the dependent variable was presence of infection by $\mathrm{KPC}$, and the independent variables tested were those who present a value of $p<0.20$, in the initial univariate analyses. All analyses were performed using the Statistical Package for Social Sciences software (SPSS 17.0, Chicago, IL, USA).

\section{RESULTS}

In the 45 patients considered cases, 277 samples were identified as positive for KPC. The site of KPC isolation in $62 \%$ of the samples was the urine culture, $25 \%$ blood culture, $9 \%$ surgical site infection (wound secretions) and $4 \%$ in tracheal aspirate.
Table 1 - Sociodemographic characteristics, etiology of chronic renal disease (ESRD) and clinical variables of interest of the case group and control, São Paulo, Brazil, 2017

\begin{tabular}{lccc}
\hline Variable & $\begin{array}{c}\text { Cases } \\
\mathbf{n = 4 5}\end{array}$ & $\begin{array}{c}\text { Controls } \\
\mathbf{N = 9 0}\end{array}$ & p-value \\
\hline Age & $47.20 \pm 12.11$ & $46.12 \pm 12.31$ & 0.325 \\
Male \% & $28(61 \%)$ & $54(59 \%)$ & 0,974 \\
Etiology & & & \\
$\quad$ glomerulonephritis & $18(40 \%)$ & $41(45 \%)$ & 0,304 \\
Polycystic kidneys & $10(22 \%)$ & $18(20 \%)$ & 0,962 \\
Undetermined & $4(10 \%)$ & $20(22 \%)$ & 0,038 \\
Others & $3(9 \%)$ & $11(13 \%)$ & 0,421 \\
Comobidities & & & \\
Hypertension & $23(52 \%)$ & $41(45 \%)$ & 0,441 \\
DM & $6(13 \%)$ & $13(14 \%)$ & 0,987 \\
Other* & $16(35 \%)$ & $46(41 \%)$ & 0,369 \\
Type of dialysis & & & \\
Hemodialysis & $41(93 \%)$ & $85(94 \%)$ & 0,953 \\
Peritoneal dialysis & $3(6 \%)$ & $3(3 \%)$ & 0,235 \\
Conservative & $1(1 \%)$ & $2(3 \%)$ & 0,378 \\
Time of dialysis, preceded months & $51.32 \pm 43.23$ & $49.92 \pm 43.11$ & 0,241 \\
Time of transplantation, months & $23.90 \pm 19.28$ & $19.91 \pm 18.32$ & 0,117 \\
Urea, mg/dl & $133 \pm 46$ & $116 \pm 43$ & 0,221 \\
Creatinine, mg/dl & $7.34 \pm 3.72$ & $6.61 \pm 3.21$ & 0,067 \\
Leukocytes $/$ mm3 & $7405 \pm 7348$ & $8831 \pm 7776$ & 0,085 \\
Hemoglobin g/\% & $11.05 \pm 1.75$ & $11.51 \pm 1.51$ & 1 \\
Hematocrit \% & $34.44 \pm 5.86$ & $36.96 \pm 5.62$ & 0,083 \\
\hline
\end{tabular}

*neoplasm and systemic lúpus erythematosus.

The sociodemographic characteristics, etiology of chronic renal disease (ESRD), comorbidities, type and duration of dialysis treatment before transplant, and the laboratory tests at entrance into the study of patients included in the study are presented in Table 1. There was no statistically significant difference between variables studied in the cases compared to controls and both group were considered homogeneous.

Infection by KPC in patient cases occurred in $73 \%$ of the occasions during hospitalization for kidney transplant, and, in $27 \%$ of episodes that occurred in the post-transplant hospitalizations related to clinical events during the first year after the transplant in the followed up period.

Table 2 - Characteristics of renal transplant and previous clinical complications of infection by KPC between cases and controls, São Paulo, Brazil, 2017

\begin{tabular}{|c|c|c|c|c|c|c|}
\hline \multicolumn{4}{|c|}{ Simple logistic regression } & \multicolumn{3}{|c|}{ Multiple logistic regression } \\
\hline Type of donor & Cases (45) & Control (90) & OR (IC95\%) & $P$ value & OR (IC 95\%) & $P$ value \\
\hline Deceased donor & $40(88 \%)$ & 83 (92\%) & $0.69(0.28-1.71)$ & 0.422 & & \\
\hline Time of hospitalization after $\mathrm{TX}^{*}$, days & $51.31 \pm 42,26$ & $12.35 \pm 18,42$ & $5.61(2,92-10,8)$ & $<0.001$ & $(4.82(2.46-9,44)$ & $<0.001$ \\
\hline Delayed kidney function & $23(49.3 \%)$ & $10(11 \%)$ & $7.85(4.00-15.39)$ & $<0.001$ & $5.60(1.91-11.01)$ & $<0.001$ \\
\hline Thymoglobulin induction & $8.2(18 \%)$ & $4.5(5,1 \%)$ & $3.04(1.14-7.91)$ & 0.017 & & \\
\hline Basiliximab induction & $10(22 \%)$ & $5(5 \%)$ & $2.97(1.19-7.10)$ & 0.015 & & \\
\hline Mycophenolic acid & $9(18.8 \%)$ & $6.39(6.5 \%)$ & $3.20(1.34-7.60)$ & 0.0006 & & \\
\hline Calcineurininhibitors & $7.65(17 \%)$ & $14.4(16 \%)$ & $3.20(1.43-7.40)$ & 0.689 & & \\
\hline Previous infection & $30(65 \%)$ & $22.5(25 \%)$ & $53.68(8.00-4.00)$ & $<0.001$ & $34.13(3.52-132.00)$ & $<0.001$ \\
\hline Acute rejection & $26(57 \%)$ & $17(19 \%)$ & $4.96(1.47-17.00)$ & 0.004 & $2.78(1.21-19.15)$ & 0.012 \\
\hline CMV infection & $14(29 \%)$ & $13(19 \%)$ & $7.60(1.60-38.00)$ & 0.003 & $9.2(2.17-24.29)$ & 0.005 \\
\hline Deaths & $12(27 \%)$ & 0 & 0 & 0 & - & $<0.001$ \\
\hline
\end{tabular}


In univariate logistic regression analysis the most significant events were: time of hospitalization after transplant (OR: 5.61 51.3 \pm 42.2 days versus $2.46 \pm 9.44$ days, $\mathrm{p}<0.001)$, delayed kidney function (OR: $7.85,49.3 \%$ versus $11 \%, \mathrm{p}<0.001)$ and use of mycophenolic acid (OR: $3.20,18.8 \%$ versus $6.5 \%, \mathrm{p}<0.006)$. Clinical events were: occurrence of previous infection by other microorganisms (OR: $53.68,65 \%$ versus $25 \%, \mathrm{p}<0.001$ ), acute rejection (OR: $4.96,57 \%$ versus $19 \%, \mathrm{p}<0.004$ ) and cytomegalovirus infection ( OR: 7.60, 29\% versus $19 \%, \mathrm{p}<0.003$ ).

Twelve (27\%) deaths occurred due to KPC infection in patient cases. The control group there was no death related to KPC or other infectious causes during the study period ( $p<0.001)$.

In the multivariate analysis using logistic regression, risk factors associated with infection by KPC were identified in Table 2.The parameters that were significantly associated with the outcome of KPC infection were: time of hospitalization (OR 4.82, Cl 2.46-9.44, $\mathrm{p}<0.001$ ), delayed kidney function (OR 5.60,Cl 1.92-11.01, $\mathrm{p}<0.001$ ), previous infections by another microoganism (OR 34.13,Cl 3.52-132.00, $\mathrm{p}<0.001$ ) and CMV infection (OR 9.20-95\% Cl2.17-24.29, $\mathrm{p}<0.005$ ).

\section{Discussion}

The analysis of risk factors for infection by KPC among renal transplant patients was the first proposition of the study. The characteristics of the groups of cases and controls were homogeneous in regard to age, sex, type of dialysis treatment, donor type and clinical conditions to analyze the exams of biochemical input.

The risk factors found for infection by KPC among patients was the length of hospital stay after transplant, delayed kidney function and requiring dialysis after transplantation and clinical complications such as previous infectious episodes and invasive cytomegalovirus that lead to invasive diagnostic procedures and greater use of antimicrobials during six months after the transplant.

In renal transplant patients, infections consist of one of the principal causes of hospital readmissions, and represent $51 \%$ of admissions that occur within six months after transplantation, preceded only by surgical complications ${ }^{(19)}$. Despite the development of surgical techniques and immunosuppressive schemes, infections remain the second leading cause of mortality among renal transplant patients ${ }^{(19-20)}$.

Previous studies with other patient populations demonstrated that hospitalization in ICU, prolonged length of hospital stay, invasive procedures, solid organ transplant and recent exposure to broad-spectrum antibiotics were directly related to infection/ colonization by $\operatorname{KPC}(6-7,9,21-25)$.

In the present study the mortality associated with infection KPC was $27 \%$, a lower rate than other studies as high as $71 \%$ in vulnerable population, solid organ transplantation ${ }^{(7,9-11)}$.

The lower mortality rate (27\%) found in this study suggested that in this service, early detection and intervention occurred. Other data that reinforced the measures of early intervention were a form of identification of the bacteria in the study population, in which $41 \%$ were obtained through surveillance of cultures.

A recent literature review about global epidemiology of KPC showed that in several studies the mortality rate was found to be similar to that found in the present study, and ranged from 13 to $34 \%$ for the groups who had early identification of bacteria and combined antimicrobial therapy ${ }^{(2)}$. McNeil et al. have evaluated the implementation of surveillance cultures for patients who were scheduled to undergo renal transplantation, and demonstrated that patients colonized before transplant have a higher morbidity when compared with those non-colonized patients ${ }^{(26)}$.

Routine rectal swab surveillance of KPC contacts is an important measure to enhance identification and isolation of carriers associate with other interventions are more likely to be successful included minimizing use of invasive devices, promotion of antimicrobial stewardship, a standardized approach for active surveillance of at risk populations, improve the hand hygiene adherence and protocols for discontinuation of carrier status ${ }^{(2,27-30)}$.

The high risk of acquiring and disseminating $\mathrm{KPC}$ in renal transplant patients is recommended as a component of infection control programs and the development of safe techniques for the rapid identification of this microorganism and the $\mathrm{qPCR}$ technique demonstrated in provides better results compared to the culture method and allows the rapid implementation of control measures and interventions to reduce the spread of health services ${ }^{(33)}$.

Confronted by infectious complications in patients with ESRD, Barbosa et al. ${ }^{(34)}$ evaluated the prevalence of colonization with vancomycin-resistant Enterococcus (VRE) in 300 patients on dialysis and 280 transplant recipients treated at Hospital do Rim e Hipertensão da UNIFESP. A prevalence rate of $14.5 \%$ was verified in dialysis, and of $14 \%$ in renal transplant recipients. With molecular typing of these samples, the important detection of cross-transmission of VRE among patients treated at the Serviço de Diálise e Transplante da UNIFESP (Dialysis and Transplant Service of UNIFESP) was possible ${ }^{(35)}$.

Cytomegalovirus (CMV) infection is the important infectious complication in kidney transplantation, specially in the first year and it is one reason for high morbidity and mortality rates. Infection for CMV increasing the risk factors for infection by KPC related to hospitalization and invasive procedures ${ }^{(31)}$.

This becomes even more important when recent studies suggest there are no differences in the survival of the patient and of the graft in renal transplant recipients receiving azathioprine or mycophenolate in combination with tacrolimus and steroids, indicating that azathioprine should be considered a therapeutic option for a selected group of patients ${ }^{(32)}$.

It was observed that most donors were deceased, reflecting the national and international policies for organ donation stimulus. In recent systematic review and meta-analysis published has revealed that deceased kidney donor recipients have 20\% higher risk for developing infections ${ }^{(36)}$

The risk factors found in this study should lead to greater vigilance in actions with this population, from hospital admission to discharge, especially the establishment of measures of prevention and control of infection, in particular the implementation of bundles that include washing of hands, surface cleaning, education of health staff, surveillance cultures, bathing with chlorhexidine, and contact precautions are among the key measures described to contain the spread of this bacteria $(2,27,30)$.

\section{Limitations of the Study}

We highlight as a study limitation the fact that the majority of the patients had renal replacement therapy in other services, and because of this further analysis was not possible to deepen the analysis. Another aspect that must be emphasized is that, because it was a retrospective 
study that made use of information obtained in patients'records, the collection and insertion of data in the database analysis were confirmed by two researchers, aiming at reliability of the results.

\section{Contributions to the Area}

As implications for practice, the need for adherence to preventive measures against infections related to health care, in particular hand hygiene, are emphasized. Early identification and infection control measures for patients at higher risk of infection as delayed kidney function and risk for infection for CMV. Identification of patients colonized by KPC in this study was probably an important measure for the reduction of mortality rates, as compared to the literature.

\section{Conclusions}

The main risk factors for infection by KPC were: time of hospitalization after the transplant, delayed kidney function and clinical events that lead to the need for invasive procedures, and consequently greater exposure to the hospital environment.

Additional measures include minimizing use of invasive devices, promotion of

antimicrobial stewardship, a standardized approach for active surveillance of at risk populations, and protocols for discontinuation of carrier status.

\section{Competing interests}

The authors declare that they have no competing interests.

\section{Acknowledgements}

We wish to acknowledge the Coordenação de Aperfeiçoamento de Pessoal de Nível Superior (Capes) and Fundação de Amparo à Pesquisa do Estado de São Paulo for the financial support for this study.

\section{REFERENCES}

1. Rossolini GM, Arena F, Pecile P, Pollini S. Update on the antibiotic resistance 438 crisis. Curr Opin Pharmacol [Internet] 2014 [cited 2019 Mar 24]; 18:56-60. Available from: https://doi.org/10.1016/j.coph.2014.09.006

2. Munoz-Price LS, Poirel L, Bonomo RA, Schwaber MJ, Daikos GL, Cormican M, et al. Clinical epidemiology of the global expansion of Klebsiella pneumoniae carbapenemases. Lancet Infect Dis 2013; 13:785-96. doi: 10.1016/S1473-3099(13)70190-7.

3. Gasink LB, Edelstein PH, Lautenbach E, Synnestvedt M, Fishman NO. Risk factors and clinical impact of Klebsiella pneumoniae carbapenemase-producing K. pneumoniae. Infect Control Hosp Epidemiol [Internet]. 2009 [cited 2019 Mar 24];30(12):1180-5. Available from: https://doi.org/10.1086/648451

4. Kwak YG, Choi SH, Choo EJ, Chung JW, Jeong JY, Kim NJ, Woo JH, Ryu J, Kim YS. Risk factors for the acquisition of carbapenem-resistant Klebsiella pneumoniae among hospitalized patients. Microb Drug Resist [Internet]. 2005 [cited 2019 Mar 24];11(2):165-9. Available from: https://doi.org/10.1089/mdr.2005.11.165

5. Orsi GB, Bencardino A, Vena A, Carattoli A, Venditti C, Falcone M, et al. Patient risk factors for outer membrane permeability and KPCproducing carbapenem resistant Klebsiella pneumoniae isolation: results of a double case-control study. Infection [Internet]. 2013 [cited 2019 Mar 24];41(1):61-7. Available from: https://doi.org/10.1007/s15010-012-0354-2

6. Patel G, Huprikar S, Factor SH, Jenkins SG, Calfee DP. Outcomes of carbapenem-resistant Klebsiella pneumoniae infection and the impact of antimicrobial and adjunctive therapies. Infect Control Hosp Epidemiol [Internet]. 2008 [cited 2019 Mar 24];29(12):1099-106. Available from: https://doi.org/10.1179/2047773215Y.0000000004

7. Freire MP, Abdala E, Moura ML, de Paula FJ, Spadão F, Caiaffa-Filho HH, David-Neto E, Nahas WC, Pierrotti LC. Risk factors and outcome of infections with Klebsiella pneumoniae carbapenemase-producing K. pneumoniae in kidney transplant recipients. Infection [Internet]. 2015;43(3):315-23. Available from: https://doi.org/10.1007/s15010-015-0743-4

8. Mathers AJ, Cox HL, Bonatti H, et al. Fatal cross infection by carbapenem-resistant Klebsiella in two liver transplant recipients. Transpl Infect Dis [Internet]. 2009 [cited 2019 Mar 24];11(3):257-65. Available from: https://doi.org/10.1097/SMJ.0b013e3181fd7d5

9. Bergamasco MD, Barroso Barbosa M, de Oliveira Garcia D, Cipullo R, Moreira JC, Baia C, et al. Infection with Klebsiella pneumoniae carbapenemase (KPC)-producing K. pneumoniae in solid organ transplantation. Transpl Infect Dis [Internet]. 2012 [cited 2019 Mar 24];14(2):198-205. Available from: 10.1111/j.1399-3062.2011.00688.x

10. Taglietti F, Di Bella S, Galati V, Topino S, lappelli M, Petrosillo N. Carbapenemase-producing Klebsiella pneumoniae-related mortality among solid organ-transplanted patients: do we know enough? Transpl Infect Dis [Internet]. 2013 [cited 2019 Mar 24];15(4):E164-5. Available from: https://doi.org/10.1111/tid.12085

11. Cicora F, Mos F, Paz M, Allende NG, Roberti J. Infections with blaKPC-2-producing Klebsiella pneumoniae in renal transplant patients: a retrospective study. Transplant Proc [Internet]. 2013 [cited 2019 Mar 24];45(9):3389-93. Available from: https://doi.org/10.1016/j. transproceed.2013.07.064

12. Centers for Disease Control and Prevention. Carbapenem-resistant Enterobacteriaceae in healthcare settings [Internet]. Atlanta (GA): CDC; 2019. Available from: http://www.cdc.gov/hai/organisms/cre/

13. Vital signs: Carbapenem - resistant Enterobacteriaceae. MMWR Morb Mortal Wkly Rep [Internet]. 2013 [cited 2019 Mar 24];62:165-70. Available from: https://www.cdc.gov/mmwr/volumes/65/wr/mm6534a5.htm 
14. Monteiro J, Santos AF, Asensi MD, Peirano G, Gales AC. First report of KPC-2-producing Klebsiella pneumoniae strains in Brazil. Antimicrob Agents Chemother [Internet]. 2009 [cited 2019 Mar 24];53(1):333-4. Available from: https://doi.org/10.1128/AAC.00736-08

15. Gales AC, Castanheira M, Jones RN, Sader HS. Antimicrobial resistance among Gram-negative bacilli isolated from Latin America: results from SENTRY Antimicrobial Surveillance Program (Latin America, 2008-2010). Diagn Microbiol Infect Dis [Internet]. 2012 [cited 2019 Mar 24];73(4):354-60. Available from: https://doi.org/10.1016/j.diagmicrobio.2012.04.007

16. Chagas TP, Seki LM, da Silva DM, Asensi MD. Occurrence of KPC-2-producing Klebsiella pneumoniae strains in hospital wastewater. J Hosp Infect [Internet]. 2011[cited 2019 Mar 24];77(3):281. Available from: https://doi.org/10.1016/j.jhin.2010.10.008

17. Horan TC, Andrus M, Dudeck MA. CDC/NHSN surveillance definition of health care-associated infection and criteria for specific types of infections in the acute care setting. Am J Infect Control [Internet]. 2008 [cited 2019 Mar 24]; 36(5):309-32. Available from: https://doi. org/10.1016/j.ajic.2008.03.002

18. Humphries RM, Ambler J, Mitchell SL, Castanheira M, Dingle T, Hindler JA et al. CLSI Methods Development and Standardization Working Group Best Practices for Evaluation of Antimicrobial Susceptibility Tests. J Clin Microbiol. 2018 Mar 26; 56(4): 01934-17. doi: 10.1128/ JCM.01934-17.

19. Moghani Lankarani M, Noorbala MH, Assari S. Causes of re-hospitalization indifferent post kidney transplantation periods. Ann Transplant [Internet]. 2009 [cited 2019 Mar 24];14(4):14-9. Available from: https://doi.org/10.1080/14756366.2018.1559840

20. 2015 USRDS Annual Data Report. Vol 2: ESRD in the United States. Washington (DC): United States Renal Data System; 2015 [cited 2019 Mar 24]. 274 p. Available from: https://www.usrds.org/2015/download/vol2_USRDS_ESRD_15.pdf

21. Falagas ME, Rafailidis PI, Kofteridis D, Virtzili S, Chelvatzoglou FC, Papaioannou V, Maraki S, Samonis G, Michalopoulos, A. Risk factors of carbapenem-resistant Klebsiella pneumonia infections: a matched case control study. J Antimicrob Chemother [Internet]. 2007 [cited 2019 Mar 24];60(5):1124-30. Available from: https://doi.org/10.1093/jac/dkm356

22. Nguyen M, Eschenauer GA, Bryan M, O'Neil K, Furuya EY, Della-Latta P, Kubin CJ: Carbapenem-resistant Klebsiella pneumoniae bacteremia: factors correlated with clinical and microbiologic outcomes. Diagn Microbiol Infect Dis [Internet]. 2010 [cited 2019 Mar 24];67(2):180-4. Available from: https://doi.org/10.1016/j.diagmicrobio.2010.02.001

23. Hussein K, Sprecher H, Mashiach T, Oren I, Kassis I, Filkenstein R. Carbapenem resistance among Klebsiella pneumonia isolates: risk factors, molecular characteristics, and susceptibility patterns. Infect Control Hosp Epidemiol [Internet]. 2009 [cited 2019 Mar 24];30(7):666-71. Available from: https://doi.org/10.1086/598244

24. Borer A, Saidel-Odes L, Riesenberg K, Eskira S, Peled N, Nativ R, Schlaeffer F, Sherf M. Attributable mortality rate for carbapenem-resistant Klebsiella pneumonia bacteremia. Infect Control Hosp Epidemiol [Internet]. 2009 [cited 2019 Mar 24];30(10):972-6. Available from: https:// doi.org/10.1086/605922

25. Correa L, Martinho MDV, Siqueira I, Pasternak J, Gales AC, Silva CV, Camargo TZC, Scherer PF, Marra AR. A hospital-based matched casecontrol study to identify clinical outcome and risk factors associated with carbapenem - resistant Klebsiella pneumoniae infection. BMC Infect Dis [Internet]. 2013 [cited 2019 Mar 24];13:80.Available from: https://doi.org/10.1186/1471-2334-13-80

26. McNeil SA, Malani PN, Chenoweth CE, Fontana RJ, Magee JC, Punch JD, et al. Vancomycin-resistant enterococcal colonization and infection in liver transplant candidates and recipients: A prospective surveillance study. Clin Infect Dis [Internet]. 2006 [cited 2019 Mar 24];42(2):195203. Available from: https://doi.org/10.1086/498903

27. Tacconelli E, Cataldo MA, Dancer SJ, De Angelis G, Falcone M, Frank U, et al. ESCMID guidelines for the management of the infection control measures to reduce transmission of multidrug-resistant Gram-negative bacteria in hospitalized patients. Clin Microbiol Infect [Internet]. 2014 [cited 2019 Mar 24];20 Suppl 1:1-55. Available from: https://doi.org/10.1111/1469-0691.12427

28. Gagliotti C, Ciccarese V, Sarti M, Giordani S, Barozzi A, Braglia C, et al. Active surveillance for asymptomatic carriers of carbapenemaseproducing Klebsiella pneumoniae in a hospital setting. J Hosp Infect [Internet]. 2013 [cited 2019 Mar 24]; 83(4):330-2. Available from: https://doi.org/10.1016/j.jhin.2012.11.024

29. Lin MY, Lyles-Banks RD, Lolans K, Hines DW, Spear JB, Petrak R, et al. The importance of long-term acute care hospitals in the regional epidemiology of Klebsiella pneumoniae carbapenemase-producing Enterobacteriaceae. Clin Infect Dis [Internet]. 2013;57(9):1246-52. Available from: https://doi.org/10.1093/cid/cit500

30. Giacobbe DR, Del Bono V, Marchese A, Viscoli C. Early carbapenem-resistant Klebsiella pneumoniae bacteraemia: should we expand the screening? Clin Microbiol Infect. 2014; 20(12):01157-8. Available from: https://doi.org/10.1111/1469-0691.12804

31. Kasiske BL, Zeier MG, Chapman JR, Craig JC, Ekberg H, Garvey CA, Green MD et al. Kidney Disease: Improving Global Outcomes. Clinical practice guideline for the care of kidney transplant recipients: a summary. Kidney Int [Internet]. 2010 [cited 2019 Mar 24];77(4):299-311. Available from: https://doi.org/10.1038/ki.2009.377

32. Schold JD, Kaplan B. AZA/tacrolimus is associated with similar outcomes as MMF/tacrolimus among renal transplant recipients. Am J Transplant [Internet] 2009 [cited 2019 Mar 24];9(9):2067-7. Available from: https://doi.org/10.1111/j.1600-6143.2009.02756.x

33. Rezende TFT, Doi AM, Quiles MG, Pignatari ACC, Manfrendi S, Grothe C, et al. Detection of colonization by carbapenem-resistant organisms by real-time polymerase chain reaction from rectal swabs in patients with chronic renal disease. J Hosp Infection. 2017 [cited 2019 Mar 24];96(20):123-8. Available from: https://doi.org/10.1016/j.jhin.2017.03.021

34. Barbosa D, Lima L, Silbert S, Sader H, Cendoroglo M, Draibe $\mathrm{S}$ et al. Evaluation of the prevalence and risk factors for colonization by vancomycin-resistant Enterococcus among patients on Dialysis. Am J Kidney Dis [Internet]. 2004 [cited 2019 Mar 24];44(2):337-43. Available 
from: https://doi.org/10.1053/j.ajkd.2004.04.038

35. Fram D, Castrucci FM, Taminato M, Godoy-Martinez P, Freitas MC, Belasco A, Sesso R, Pacheco-Silva A, Pignatari AC, Barbosa D. Crosstransmission of vancomycin-resistant Enterococcus in patients undergoing dialysis and kidney transplant. Braz J Med Biol Res [Internet]. 2010 [cited 2019 Mar 24]; 43(1):115-9. Available from: http://dx.doi.org/10.1590/S0100-879X2009007500023

36. Taminato M, Fram D, Grote C, Pereira RRF, Belasco A, Barbosa D. Prevalence of infection in kidney transplantation from living versus deceased donor: systematic review and meta-analysis. Rev Esc Enferm USP [Internet]. 2015;49(3):502-507. Available from: http://dx.doi. org/10.1590/S0080-623420150000300020 